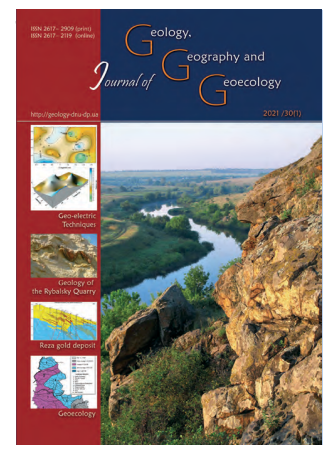

Journal of Geology.

\title{
Impact of economic activity on geoecological transformation of the basin of the Zhovtenka River (Ukraine)
}

\author{
Vasyl H. Andreev ${ }^{1}$, Hennadii V. Hapich², Volodymyr V. Kovalenko² \\ ${ }^{I}$ Institute for Nature Management Problems and Ecology of National Academy of Sciences of Ukraine, Dnipro, Ukraine, \\ AndreevVG@ukr.net \\ ${ }_{2}^{2}$ Dnipro State Agrarian and Economic University, Dnipro, Ukraine, gapichgennadii@gmail.com
}

\section{Received: 07.05.2020 \\ Received in revised form: 19.05 .2020 \\ Accepted: 09.12.2020}

Abstract. The article presents the results of the study on the current geoecological condition of the basin of the Zhovtenka River. The study object corresponded to the criteria of a small river, having the length of $42 \mathrm{~km}$ and the area of the drainage basin of $293 \mathrm{~km}^{2}$. According to the geographic peculiarities and the level of anthropogenic impact it is a typical small river of the Ukrainian Steppe zone. At the current stage of water management, the river and its tributaries are significantly regulated by artificial aquatic objects - ponds and a water reservoir. The total number of hydrotechnical facilities that form the water bodies is 34 levees. On the river itself, average density of water bodies equals 1 pond per every $2 \mathrm{~km}$ of the river length. Such regulation contradicts the norms of the current water protection legislation of Ukraine. As a result of fragmentation, the river has turned into a cascade of evaporation ponds. Special ecological threat to water use is the quality of water in the ponds. We determined that due to absence of current and low water exchange, the saline content in water undergoes significant changes. During the field surveys, we collected samples and determined the parameters of mineralization, content of chlorides and sulfates in 10 water bodies. Sampling was carried out during the year in different seasons. We determined that the averaged parameters of mineralization level change within the range of $9.000 \mathrm{mg} / \mathrm{dm}^{3}$ in spring to $13.000 \mathrm{mg} / \mathrm{dm}^{3}$ in summer and autumn. The content of chlorides varies within 2.600-3.600 $\mathrm{mg} / \mathrm{dm}^{3}$, sulfates $-4.000-4.800 \mathrm{mg} / \mathrm{dm}^{3}$ according to the similar seasonal dependence. Due to changes in the climatic conditions and current tendencies of warming and dry climate, decrease in the water resources heightens the risks of irreversible geoecological degradation of the river. Significant regulation and evaporation-caused loss of water leads to rapid shoaling of the water bodies and growth of aquatic-marsh vegetation. The authors suggest an approach to assessment of the level of geoecological transformation of the river basin based on determining quantitative parameters of the constituents of the elements of natural ecosystems and elements of negative anthropogenic impact. We proposed calculation of various coefficients (indicators) which alter the natural condition of water ecosystems, particularly: coefficients of fragmentation, coefficients of urbanization, coefficients of alienation, etc. We present a possibility of using them in relation to the length of the river and hydrographic network, as well as the area of drainage. We determined that percentage parameter of geoecological impact was seen in $94.3 \%$ of the area of the drainage basin or $87.4 \%$ of the river length. We suggest approaches that would minimize the deleterious impact of economic activity and gradually restore the condition of aquatic ecosystem of the river. The article provides recommendations of using coefficients of geoecological transformation of river ecosystems.

Key words: river basin, geoecological transformation, ecological safety, artificial water bodies

\section{Вплив господарської діяльності на геоекологічну трансформацію басейну річки Жовтенька (Україна)}

\author{
В. Г. Андрєєв ${ }^{1}$, Г. В. Гапіч², В. В. Коваленко
}

${ }^{1}$ Iнститут проблем природокористування та екології НАНУ, Дніпро, Україна, Andreev_V_G@ukr.net ${ }^{2}$ Дніпровський державний аграрно-економічний університет, Дніпро, Україна, gapichgēn̄adii@gmail.com

Анотація. У статті представлено результати дослідження сучасного геоекологічного стану басейну річки Жовтенька. Об’єкт досліджень відповідає критеріям малої річки з довжиною 42 км та площею водозбірного басейну 293 км². За географічними особливостями та рівнем антропогенного впливу є типовою малою річкою степової зони України. На сучасному етапі водогосподарської діяльності, річка та іiї притоки значно зарегулювані штучними водними об'єктами - ставками $\mathrm{i}$ водосховищем. Загальна кількість гідротехнічних споруд, що формують водойми, складає 34 греблі. Безпосередньо на річці середня щільність розташування водойм складає 1 ставок на кожні 2 км довжини річки. Таке зарегулювання суперечить нормам чинного водоохоронного законодавства України. Внаслідок фрагментації річка перетворилась на каскад ставків- 
випаровувачів. Особливу екологічну небезпеку водокористування становить якість води у ставках. Визначено, що через відсутності течії і низького водообміну значно змінюється сольовий склад води. В ході польових досліджень проведено відбір проб та визначені показники мінералізації, вмісту хлоридів і сульфатів у 10 водоймах. Відбір проб виконувався протягом року за різними сезонами. Встановлено, що усереднені показники рівня мінералізації змінюються в межах від 9000 мг/дм ${ }^{3}$ навесні до 13000 мг/дм³ влітку та восени. Вміст хлоридів коливається в межах 2600-3600 мг/дм², сульфатів 4000-4800 мг/дм³ за аналогічною сезонною залежністю. У зв'язку зі зміною кліматичних умов та сучасних тенденцій потепління і посушливості клімату, зниження водності підвищує ризики безповоротної геоекологічної деградації річки. Значне зарегулювання та втрати води на випаровування призводять до стрімкого обміління водойм та заростання водно-болотяною рослинністю. Авторами запропоновано підхід щодо оцінювання рівня геоекологічної трансформації річкового басейну, який спирається на визначенні кількісних показників складових елементів природної екосистеми та елементів негативного антропогенного впливу. Запропоновано оцінювати різні коефіцієнти (показники), що змінюють природний стан водних екосистем, а саме: коефіцієнти фрагментації, коефіцієнти урбанізації, коефіцієнти відчужень тощо. Представлена можливість їх застосування як за довжиною річки та гідрографічної мережі, так і за площею водозбору. Встановлено, що відсотковий показник негативного геоекологічного впливу спостерігається на 94,3\% площі водозбірного басейну або $87,4 \%$ за довжиною річки. Запропоновано підходи, що дозволять мінімізувати негативний вплив господарської діяльності та поступово відновити стан водної екосистеми річки. Наведені рекомендації прикладного застосування коефіцієнтів геоекологічної трансформації річкових екосистем.

Ключові слова: басейн річки, геоекологічна трансформачія, екологічна безпека, штучні водойми

\section{Introduction.}

Hydrotechnical construction has a history of around 5 thousand years. In all the continents (except Antarctica), millions of dams and flood-prevention levees have been constructed in small and large rivers, thus elevating hydroenergetics, water supply, transport, fish farming, recreation, and sport to a new level of development. Levees reduced the threat of floods and allowed people to settle and cultivate productive alluvial soils in the floodplains of rivers, and work on aquatic meliorations. The hydrotechnical construction peaked in the last 100 years.

Having considered the high importance of artificial water bodies for increase in available-to-use aquatic resources in farming (Hogeboom et all., 2018), we should note that non-systemic, often not correlated with the general plan, creation of water reservoirs and ponds on small rivers, which moreover is often performed at low engineer level, may have unfavourable economic and ecological consequences (Yatsyk et al., 1991).

At the same time it has to be noted that despite the great role of small rivers in the formation of natural environment and runoff of large watercourses (Lapsenkov, 1983), the study of their hydrological and hydrochemical regime is of episodic, non-systemic character. Often small rivers remain without monitoring, care, control and protection.

The increasing demand for restoration of ecological balance of complex technonatural ecosystems is currently leading scientists to pay attention to historical aspects of development and functioning of watercourses (Manyuk, 2017), and moreover the need for studying contemporary tendencies of geoecological transformation is becoming relevant. The performed studies focus on the hydrological characteristics of rivers of the steppe zone of Ukraine (Dovhanenko et all., 2017), hydrochemical parameters of quality of aquatic resources (Rudakov L. et all., 2020) and effect of chemical composition of atmospheric precipitations on their formation (Khilchevskyi et all., 2018, 2019). Largely, developing studies are those using modern geoinformational systems and technologies (Kulikova et all., 2018; Rebati et all., 2019; Shevchuk et all., 2019). In all the studies the authors try to directly or indirectly assess the ecological condition of aquatic ecosystems. Currently, there are scientific approaches to integral assessment of ecological stability of geosystems (Dmitriev et all., 2012, 2016) and their ecological balance (Reimers, 1990), which are mostly based on taking into account biotic (natural) components.

At the same time, much less attention is paid to study of construction and exploitation of hydrotechnical facilities as technical components of the elements of influence on aquatic objects (Yu-jun et all., 2019; Andrieiev V. et all., 2020). In particular, construction of levees provokes a number of negative effects related to transformation of hydrological, hydrobiologi$\mathrm{cal}$ and sanitary regimes of rivers. After levees are exploited for a long period of time and also due to their incorrespondence with the norms of reliability and safety, there occur ecological risks of hydrodynamic emergencies (Hapich, 2019). Currently, non-systemic regulation of small and average rivers with numerous violations of the norms of current legislation (Vodnyi Kodeks Ukrainy, 1995) has led to the creation of cascades of artificial water bodies and transformation of river ecosystems into aquatic-marshland areas.

Positive global experience and attitude to regulation of river runoff of small watercourses demonstrates the necessity of and tendency to dismantling of levees, restoration of the current and ecosystem of small rivers (Bednarek, 2001; Fuller et all., 2015; Magilligan et all., 2016) 
The objective of our study was creating and substantiating a theoretical model of the effect of economic activity on geoecological transformation of basins of small rivers of the steppe zone of Ukraine on the example of the Zhovtneva River. Theoretical analysis of the literature sources (Reimers, 1990; Yatsyk et all., 1991; Dmitriev et all., 2012, 2016) allowed us to form the term "geoecological transformation of river basin" as change driven by the influence of the natural and anthropogenic factors of ecological condition of aquatic objects on drainage of rivers, which leads to subsequent changes in: biocenoses, hydrological regime of watercourse, stream bed deformations, etc.

\section{Materials and methods.}

Methods of the study were based on primary empirical researches, the so-called "protocol propositions" which consist of recording the results of singular observations. During 2019-2020 the authors selected water samples from the ponds of the Zhovtenka River. The samples were taken four times in four different seasons of the year. We performed laboratory studies with assessment of the general level of mineralization, chlorides and sulfates in the water, visual diagnostic observations, including taking photos of current condition of the aquatic objects. In the research we used mathematical and analytical methods of analysis of the obtained results using modern geoinformational systems and software complexes QGIS and Microsoft Excel.

\section{Results and discussion.}

The Zhovtenka River (Fig. 1) is a typical small river of the basin of the Dnipro. It runs through the territory of Sofiivka and Apostolove Districs of Dnipropetrovsk Oblast. The length of the river without tributaries is $42 \mathrm{~km}$. The area of the drainage accounts for $293 \mathrm{~km}^{2}$. The average stream gradient is $1.5 \%$.

The river's runoff is formed chiefly by the atmospheric precipitations on average amounting to $400-430 \mathrm{~mm}$ annually. The greatest average monthly discharges of water are observed in March-April, the least (almost zero) - in late summer or early autumn. River recharge by groundwater is low and not sustainable.

Active use of the lands around the basin of the Zhovtenka River began in the late XVIII and early XIX centuries. Already at that period, try pattern of the climate and deficiency of aquatic resources determined the necessity of creating ponds for guaranteed water supply throughout the year. The ponds were small in size and were made directly near the settlements. Until the mid-XIX century, there were 2 small ponds on the stream bed of the river and 2 more on the tributaries. In the mid-XX century the number of ponds was 6 . By the early XXI century, the quantity of the ponds had increased up to 31 , including 16 facilities in the stream bed of the river and 15 on the tributaries. Furthermore, one water reservoir of $3.547 \cdot 10^{6} \mathrm{~m}^{3}$ capacity has been built in the ravine of the Vovcha. According to the data of technical inventory checking, the total extent of the regulation of the Zhovtenka River accounted for $6.393 \cdot 10^{6} \mathrm{~m}^{3}$.

Within the framework of the studies, we carried out field studies of separate hydrological parameters of the Zhovtenka River: characteristics of the runoff (water discharges) of the river and saline content in the water. To assess the hydrological parameters, we determined 10 control stations in the upper and middle flow of the river, both the stream bed and the tributaries.

Monitoring results of visual examination indicate that there was no water seepage in the lower canal pounds of the levees in all the control stations during the period from May 2019 to February 2020. The content of chlorides and sulfates, and also mineralization of water in the ponds do not depend on the order of installment of the stations, but there was seen a tendency towards increase in the concentration during the period of observations.

Fig. 2 presents average data on concentration of chlorides, sulfates and mineralization of water in ponds in 10 control stations of the upper and middle parts of the basin of the Zhovtenka River. Mean mineralization of water in the ponds may be compared to mineralization of water in the Azov Sea.

It has to be noted that one of the causes of high mineralization may have been the water from the retention pond of discharge water effluent from the water treatment facilities of Kryvy Rih and which was used for irrigation. At the same time, their overall mineralization did not exceed $1500 \mathrm{mg} / \mathrm{dm}^{3}$, and the system of irrigation and water pumping was destroyed in the mid 90s. An additional factor was chemical analyses of water in ponds located upstream, where there is seen high content of dry residuals. Thus, we can state that the situation with significant deterioration of quality of water resources is much more complex in character. The factors of impact include economic development in the territories, which causes influx of a large amount of polluting substances; the long period of irrigated agriculture which affects the discharge of highly-mineralized drainage water into the river; construction of a large amount of artificial water bodies which have completely obstructed the current of the river and turned it into a cascade of evaporators, resulting in violation of the conditions necessary for sanitary water norms. During the warm period, 


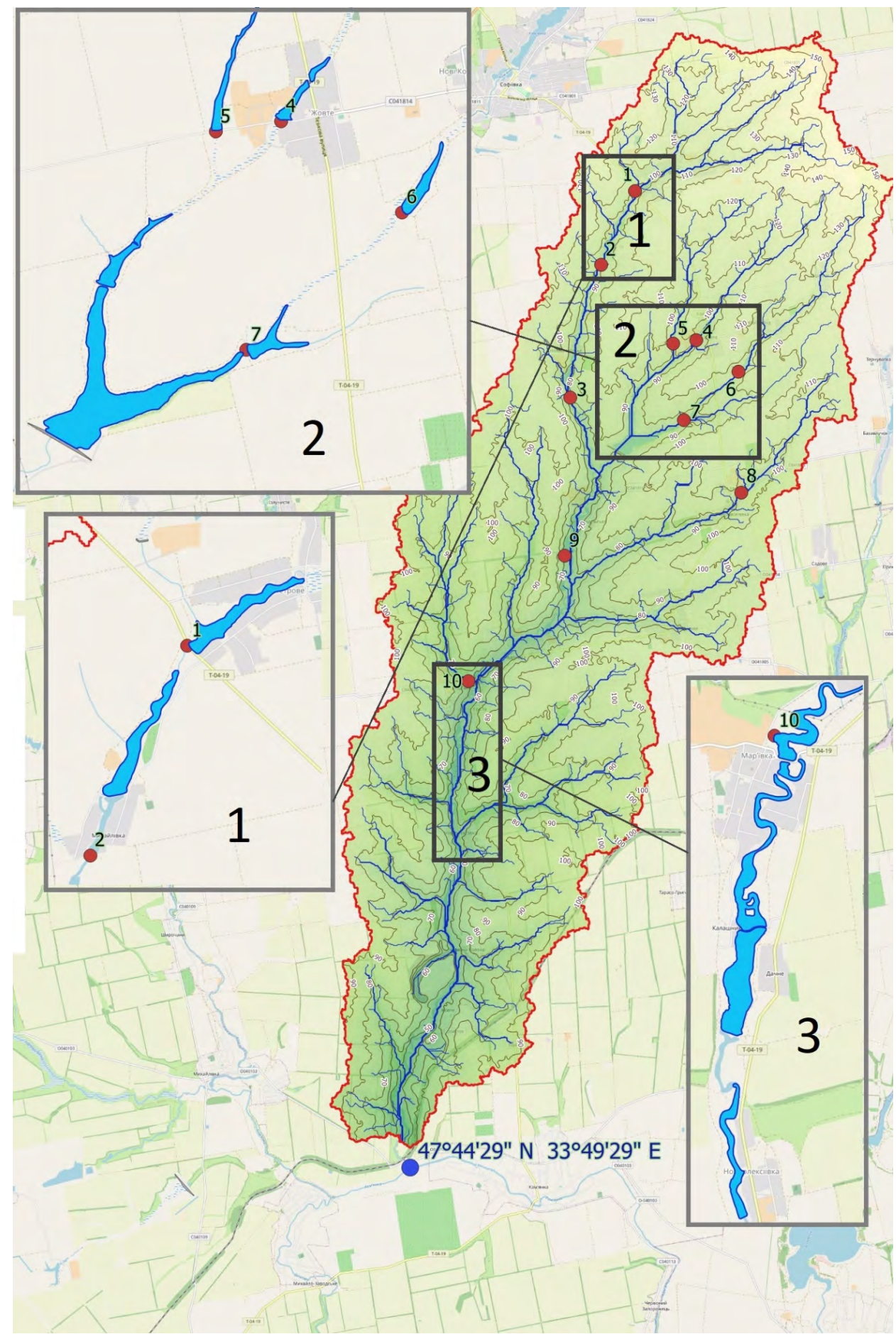

Fig. 1. Geoinformational network of the Zhovtenka River with points of selection of water samples (performed by the authors using geoinformational system QGIS)

the concentration of dry residuals in the water bodies increases, while oxygen-saturation decreases. All the mentioned factors create conditions for negative geoecological transformation of the river basin and loss of self-cleaning ability of the river. The assessment of the impact of each separate element may be a relevant task for further studies. Fig 3 presents parameters of mineralization of water in the ponds which sequentially located along the current in the stream of the Zhovtenka River.
The obtained parameters of mineralization of water suggest that the ponds are functioning as evaporation ponds. These conclusions are supported by the fact that the loss of runoff due to additional evaporation from the water surface of the ponds and small water reservoirs reduces the water resources in the Steppe zone by $5-7 \%$ in averagely humid years and by $20-40 \%$ in low-moisture years (Yatsyk et all., 1991). As an example, Fig. 4 presents the dynamics of degradation of a water body in the basin of the Zhovtenka. 


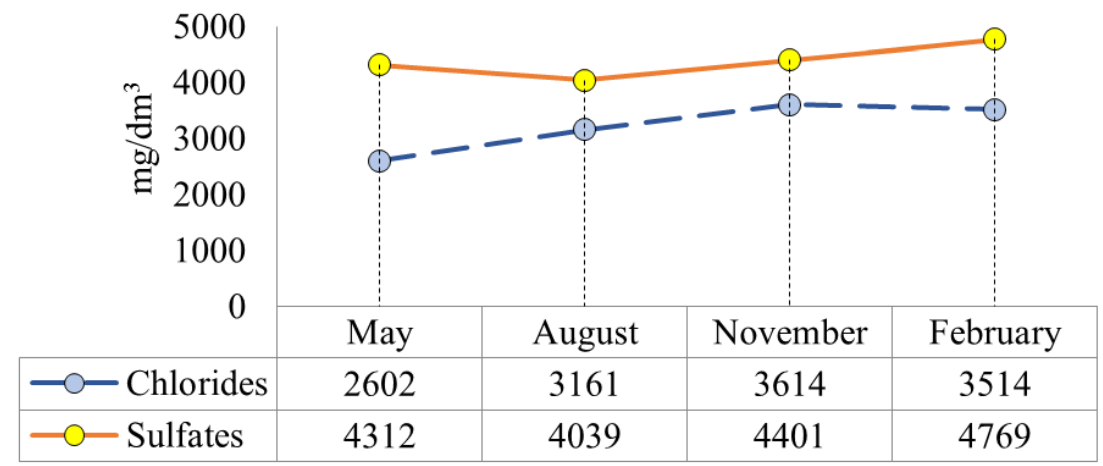

a

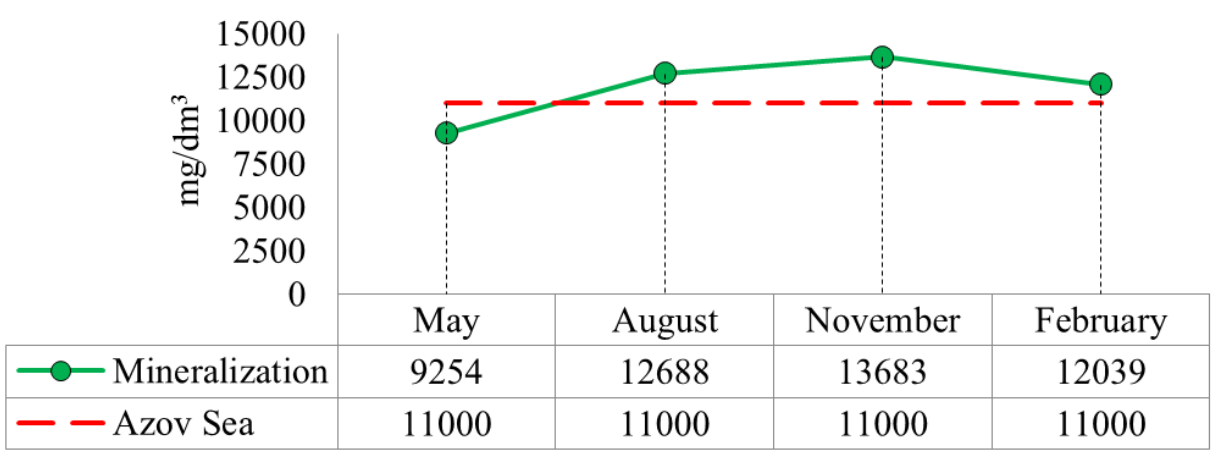

b

Fig. 2. Mean parameters of saline content (a) and mineralization of water (b) in the ponds of the basin of the Zhovtenka River (sampling took place in 2019-2020 in the authors`survey).

Obviously the water with high salt content does not meet the requirements to water quality for drinking and agricultural water supply. According to the criteria of assessment of quality of irrigation water, as regulated by the National Standard of Ukraine DSTU [Ukr. ДСТУ] 2730:2015 "Quality of natural water for irrigation. Agronomic criteria", water in the ponds is not appropriate for irrigation. It is also inappropriate for fish breeding. Thus, one can state absence of conditions for observance of ecologically safe water use in the basin of the Zhovtenka.

The field and laboratory surveys substantiate the necessity of further analysis of the situation with use of geoinformational systems and mathematical methods of analysis. To assess the level of geoecological transformation of the basin of the Zhovtenka River, the authors have for the first time proposed introducing the coefficient of the river fragmentation $\left(\mathrm{K}_{f r}\right)$ and other assessment parameters which may be used to compare the impact parameters along the length or across the area of a surveyed object. Coefficients of geoecological impact are frequency of anthropogenic changes in the ecosystem which no doubt has a close relationship with the degree of the geoecological transformation of the river basin:

1) Coefficient of fragmentation of the river is suggested to be calculated using the ratio of the total number of artificial aquatic objects to the length of the river or the area of the territory (administrative region, district, drainage basin) where they are located:

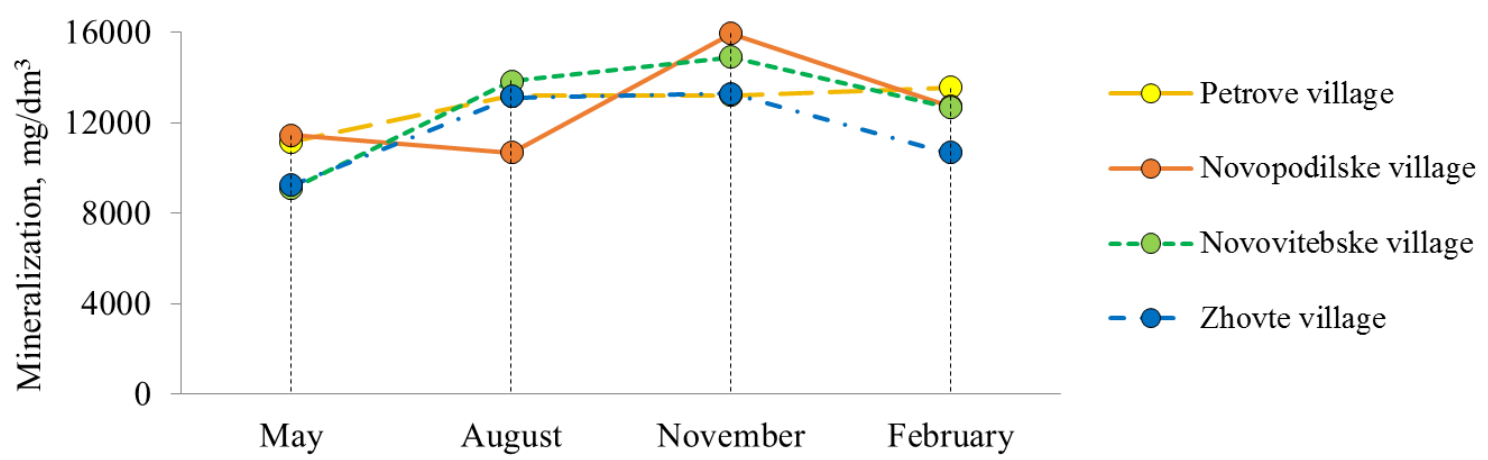

Fig. 3. Dynamics of the changes in mineralization of water in the ponds of the upper part of the basin of the Zhovtenka River (the samples were taken in the settlements in 2019-2020, the authors`survey) 


$$
\begin{aligned}
& K_{f r}^{l}=\frac{N}{L}, \\
& K_{f r}^{S}=\frac{N}{S},
\end{aligned}
$$

where $L$ - length of the river, $\mathrm{km} ; S$ - the area of the territory, $\mathrm{km}^{2} ; N$ - total amount of the levees on the river.

2) The coefficient of urbanization of the river ratio of the length of the settlements along the bank strip of the river or ratio of the area of the urbanized territory to the drainage area of the river basin:

$$
\begin{gathered}
K_{u r b}^{l}=\frac{L_{u r b}}{L_{r b}}, \\
K_{u r b}^{s}=\frac{S_{u r b}}{S_{r b}},
\end{gathered}
$$

where $L_{u r b}$ - the length of the territory along the bank line of the river where construction has been done, km; $L_{r b}$ - the length of the river basin; $S_{u r b}-$ the area of the urbanized territory, $\mathrm{km}^{2} ; S_{r b}$-drainage area of the river basin, $\mathrm{km}^{2}$.

3) Coefficient of alienation of hydrographic network as a result of the economic activity and exhaustion of the outlets of the river network and the tributaries of different order:

$$
\begin{gathered}
K_{p r}^{l}=\frac{L_{p r}}{L_{r b}}, \\
K_{d p r}^{s}=\frac{S_{d p r}}{S_{r b}},
\end{gathered}
$$

where $L_{p \mathrm{r}}$ - is the length of elements of hydrographic network which were ploughed (are currently in the land use) as a result of economic activity, km; $S_{d r b}$ - the area of the alienation of the elements of the hydrographic network of the territory, $\mathrm{km}^{2}$.

Implementation of the proposed approach allowed us to determine the main elements of assessment. We determined that 18 ponds are located on the river, and the total amount of the objects in the river basin is 34 . We should note that field surveys and use of GIS-technologies allowed us to determine more hydrotechnical facilities than there are recorded in the declared data of passportization in the management institutions, which is 31 artificial water bodies. Within the drainage basin, there are 16 settlements (Fig. 5).

Quantitative characteristics of the constituents of the formulae (3-6) were determined through the analysis of digital model of drainage (DMD) of the Zhovtenka River in GIS QGIS and combined visual analysis of high-quality cosmic images (Google Earth). Particularly, the length and area of the ploughed hydrographic network was estimated using geomorphological and hydrological analyses of

\begin{tabular}{|c|c|c|c|c|c|c|c|c|}
\hline 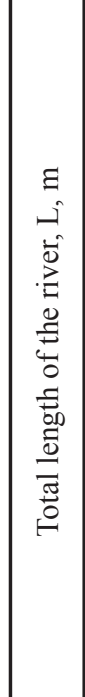 & 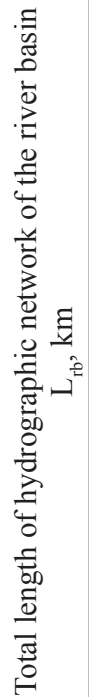 & 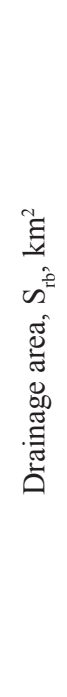 & 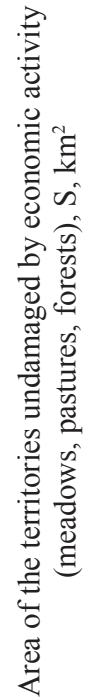 & 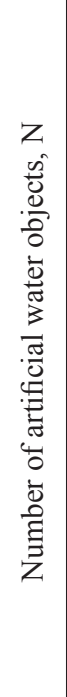 & 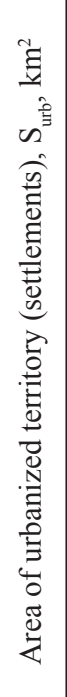 & 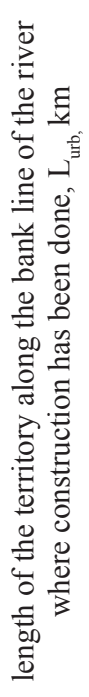 & 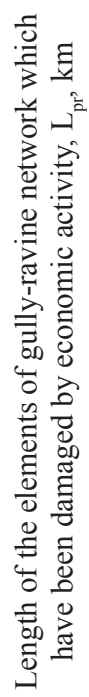 & 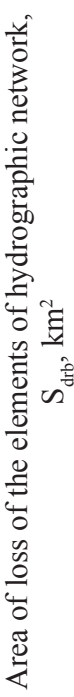 \\
\hline 42 & 161 & 293 & 16.65 & 34 & 21 & 29 & 150 & 3.0 \\
\hline
\end{tabular}
drainage in GIS, differentiative buffer analysis of hydrographic network outside the range of the water course and gully-ravine system (Fig. 6).

Table 1. Determined parameters of the main geoecological elements of the basin of the Zhovtenka River.

Through the calculations we determined that the total parameter of coefficient of the fragmentation of the river by artificial water bodies is 0.212 . The calculation of this parameter only along the length of the river itself (not taking into account the tributaries) equaled 0.429 , which is twice higher. That means a pond per each $2 \mathrm{~km}$. If we consider the natural ecological condition of the river and its drainage basin as a conditional 1 , and further gradually substract all the components of the negative impact, we shall receive the following results:

Taking into account all coefficients of negative impact for the length $1-0.212-0.180-0.482=0.126$, i.e. only $12.6 \%$ of the river is in conditionally natural state;

Taking into account all coefficients of negative impact for the area (without consideration of agricultural lands) $1-0.116-0.072-0.010=0.802$.

The area of the lands of the aquatic fund, particularly shoreline-protective strips and protected aquatic zone is the main parameter which characterizes the geoecological transformation of the river basin. Such a territory being in the natural condition of drainage 


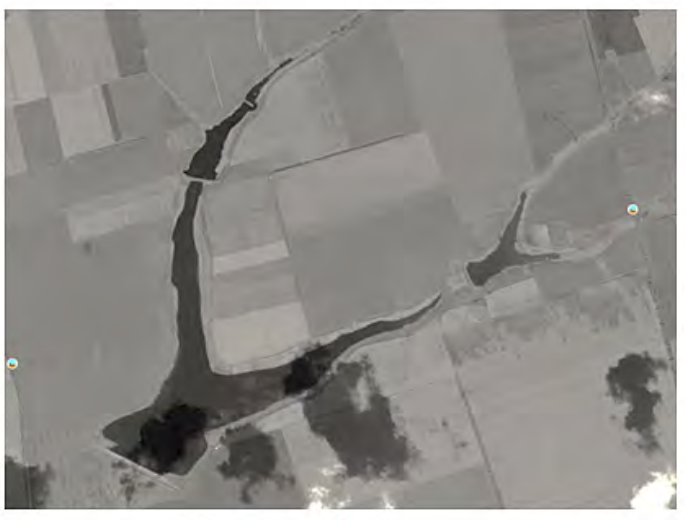

a

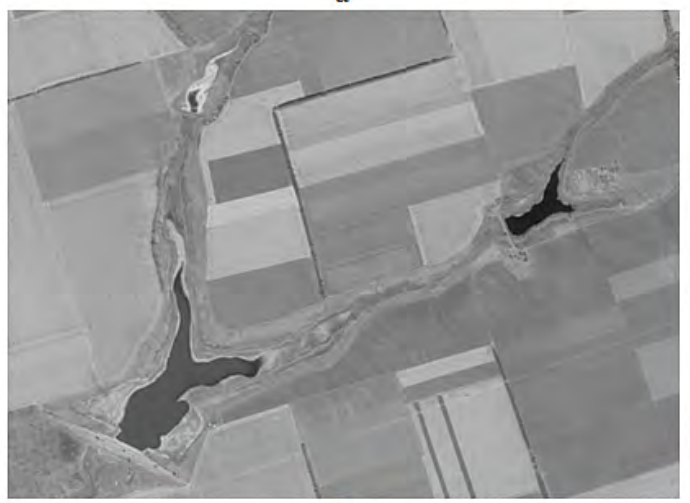

b

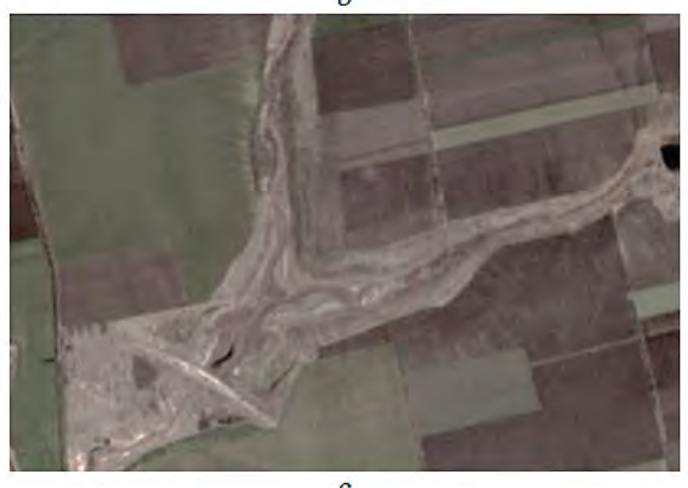

$\mathrm{c}$

with meadows, pastures and forests accounts for only $16.65 \mathrm{~km}^{2}$ or $5.7 \%$.

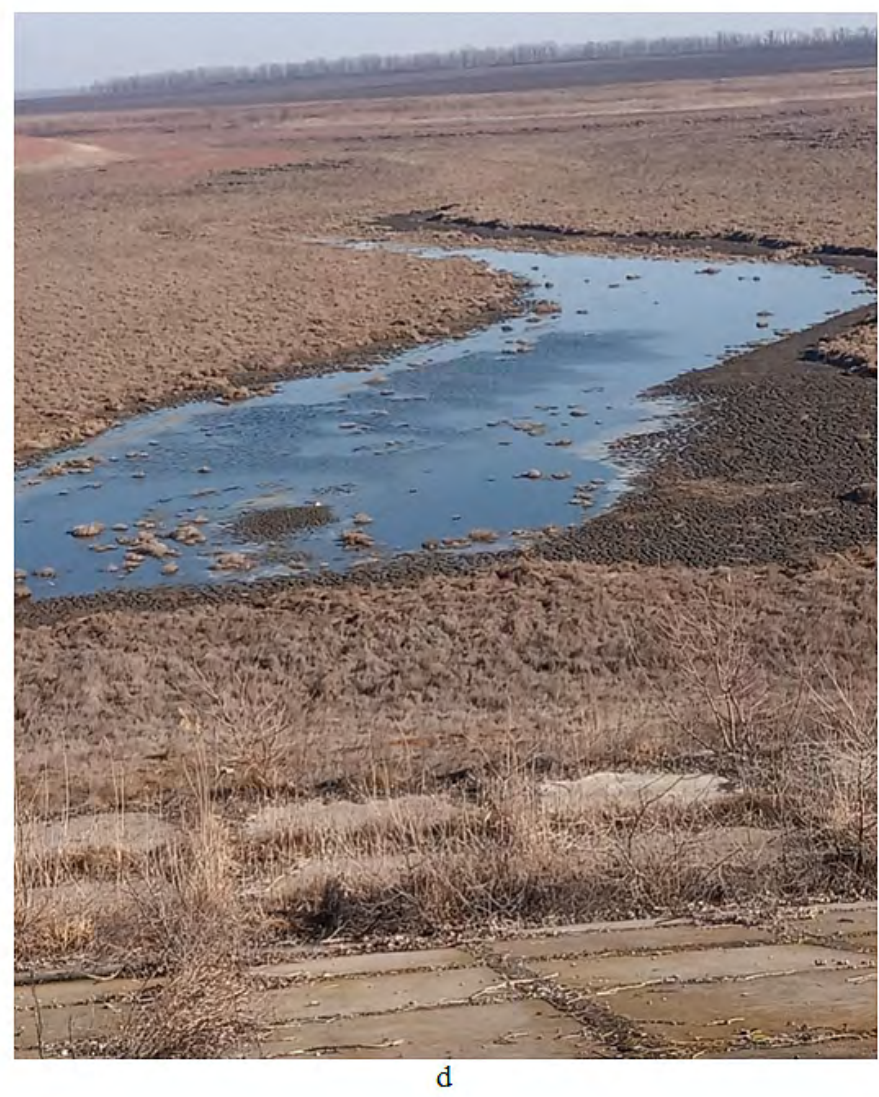

Fig. 4. Dynamics of degradation of the water reservoir in the Vovcha Ravine on the Zhovtenka River (dates when images were taken): a 04.07.2010, b-21.09.2017, c-10.03.2020 (source-Google Earth), d01.03.2020 (source - author's photo)

ploughing. Around $94 \%$ of the drainage area of the Zhovtenka River basin has been drastically damaged

Table 2. Calculation of parameters of geoecological impact of economic activity in the basin of the Zhovtenka River.

\begin{tabular}{|c|c|c|c|c|c|}
\hline \multicolumn{2}{|c|}{ Coefficient of river fragmentation } & \multicolumn{2}{c|}{$\begin{array}{c}\text { Coefficient of urbanization of the } \\
\text { river }\end{array}$} & \multicolumn{2}{c|}{$\begin{array}{c}\text { Coefficient of alienation of } \\
\text { hydrographic network }\end{array}$} \\
\hline Along the length & Across the area & Along the length & Across the area & Along the length & Across the area \\
\hline$K_{f r}^{l}$ & $K_{f r}^{s}$ & $K_{u r b}^{l}$ & $K_{u r b}^{s}$ & $K_{p r}^{l}$ & $K_{d p r}^{s}$ \\
\hline 0.212 & 0.116 & 0.180 & 0.072 & 0.482 & 0.010 \\
\hline
\end{tabular}

\section{Conclusions.}

The results of the field surveys of the Zhovtenka River indicate that agricultural activity in the river basin exerts a destructive impact on the condition of its ecosystem.

As a result of intensive arable farming all the outlets of the streams and watercourses of the hydrographic network of the river basin, accounting for the total length of $150 \mathrm{~km}$, have been damaged by by economic activity. The negative impact along the river's length was seen on over $87 \%$ of the length of the hydrographic network.

The main factors of the destructive processes include irrational construction of a large number of ponds, which has had an extremely negative effect on the discharge characteristics of the river and selfcleaning ability. The river has been transformed into a cascade of evaporation ponds, the quality of water 


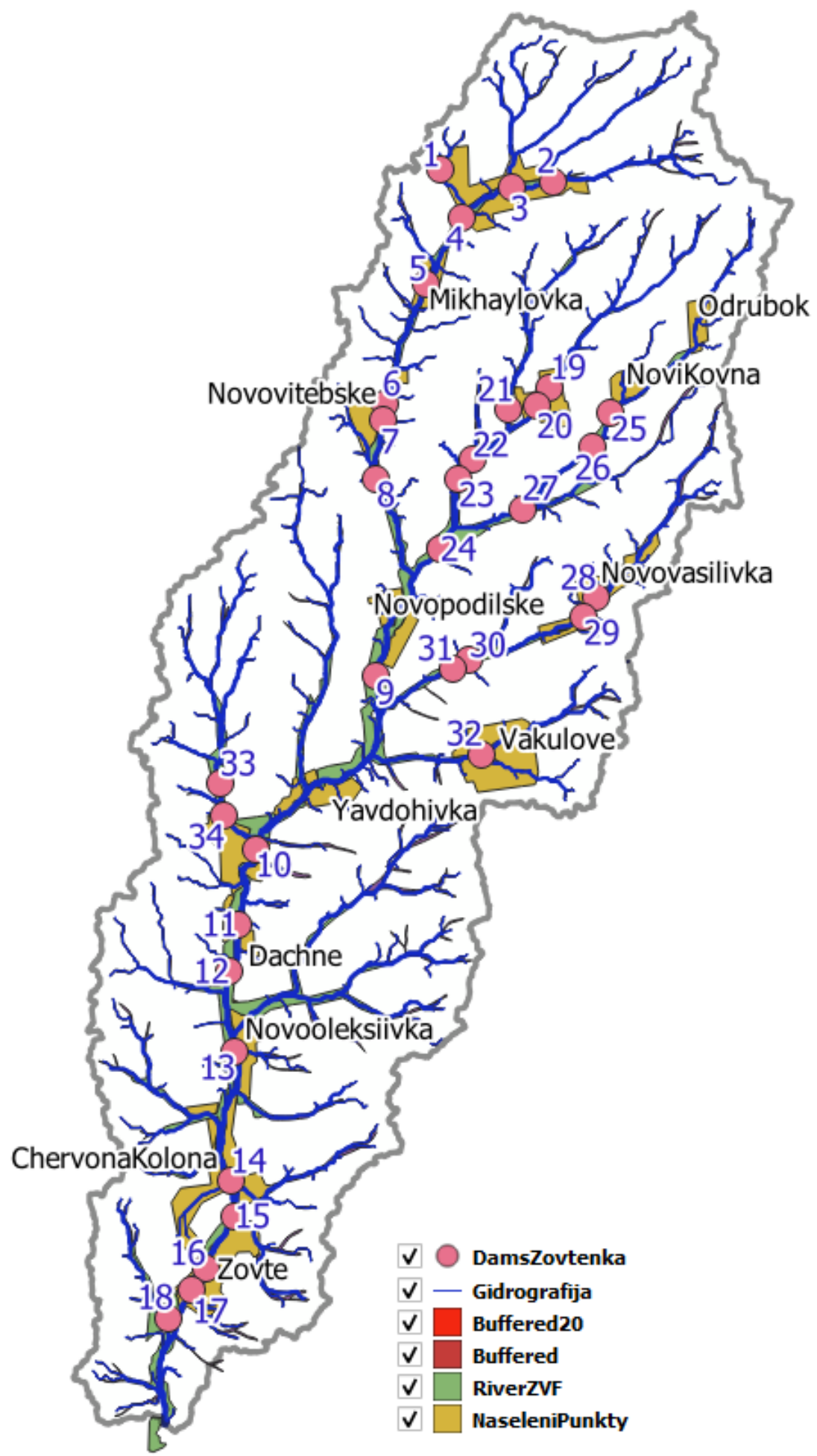

Fig. 5. Results of the surveys of the impact of economic activity on geoecological transformation of the river basin of the Zhovtenka using QGIS geoinformational system (authors` development).

in which does not meet the requirements for use for economic purposes.

To restore the hydrological regime and geoeconomic condition of small rivers, it is relevant to carry out further surveys with the purpose of determining the actual number of artificial water bodies and perform ecological-economic substantiation of expedience of their further use.
It is necessary to evaluate how the norms of the current water protection legislation are fulfilled, particularly the requirements of the Water Code of Ukraine as determined in article 82 "Regulation of the runoff of the rivers, creation of artificial water bodies".

Today, there are no generalized results of evaluation of ecological condition of small rivers of 


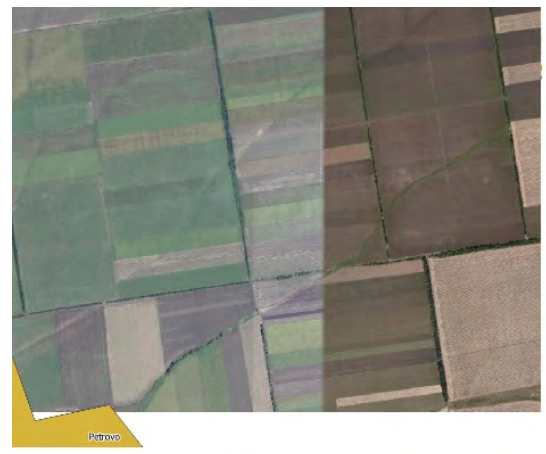

a

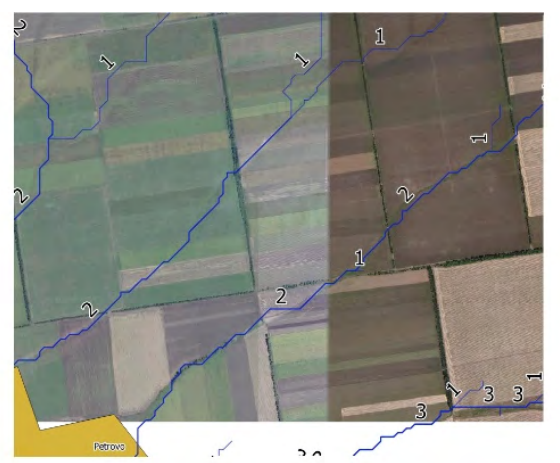

$\mathrm{b}$

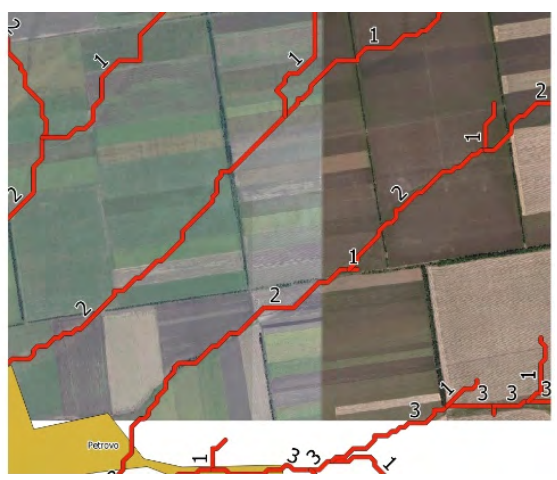

c

Fig. 6. To determine length and areas of ploughed hydrographic network: a - photo of the northern part of the drainage (Google Earth); $b$ - automated determination of hydrographic network by analysis of data of DMD in QGIS; $\mathrm{c}$ - buffer analysis of ploughed erosive areas according to the range of water stream (ravine).

Dnipropetrovsk Oblast and the majority of the water courses of the Steppe zone of Ukraine. Therefore, it is necessary to consider the possibilities to restart the work on passportization of small rivers of Dnipropetrovsk Oblast, which has not been conducted since the early 1990s.

Thus, coefficients of the geoecological impact of economic activity are recommended to be used as criteria of assessment of: the extent of anthropogenic impact; category of complexity and class of consequences (responsibility) of the objects of hydrotechnical infrastructure (construction); during development of projects for assessment of impact on the environment; results of monitoring surveys, etc.

\section{References}

Andrieiev V., \& Hapich H., 2020. Impact of ponds and reservoirs construction on the environmental safety of small river basins of the steppe zone of Ukraine (the case of Dnipropetrovsk region). Land Reclamation and Water Management, (1), 158166. Retrieved from https://doi.org/10.31073/ mivg202001-228.

Bednarek, A., 2001. Undamming Rivers: A Review of the Ecological Impacts of Dam Removal. Environmental Management. 27. 803-814. Retrieved from https://doi.org/10.1007/s002670010189.

Dmitriev, V. V., \& Ogurtsov, A. N., 2012. Podhodyi k otsenke i GIS-kartografirovaniyu ustoychivosti i ekologicheskogo blagopoluchiya geosistem. I. Integralnaya otsenka ustoychivosti nazemnyih i vodnyih geosistem [Approaches to the assessment and GIS mapping of the stability and ecological well-being of geosystems. I. Integral assessment of the stability of terrestrial and aquatic geosystems]. Bulletin of St. Petersburg University. Ser. 7. Geology. Geography. 3. 65-78 (in Russian).

Dmitriev, V. V., Fedorova, I. V., \& Biryukova, A. S., 2016.
Podhodyi k integralnoy otsenke i gis-kartografirovaniyu ustoychivosti i ekologicheskogo blagopoluchiya geosistem. Chast IV. Integralnaya otsenka ekologicheskogo blagopoluchiya nazemnyih i vodnyih geosistem [Approaches to the integrated assessment and histographic mapping of the stability and ecological well-being of geosystems. Part IV Integral assessment of the ecological well-being of terrestrial and aquatic geosystems]. Bulletin of St. Petersburg University. Ser. 7. Issue 2. 37-53. Retrieved from DOI:10.21638/11701/ spbu07.2016.204 (in Russian).

Dovhanenko, D., Horb, A., Serdiuk, S., Lunova, O., \& Dotsenko, L., 2017. A study on flood runoff of the steppe river based on the modern trends of precipitation for-mation in Dnipropetrovsk region. Journal of Geology, Geography and Geoecology. 25(2). 38-48. Retrieved from https://doi. org/10.15421/111718.

Fuller, M. R., Doyle, M. W., \& Strayer D. L., 2015. Causes and consequences of habitat fragmentation in river networks. Ann. N.Y. Acad. Sci. Issue: The Year in Ecology and Conservation Biology. 31-51. Retrieved from doi: 10.1111/nyas. 12853 .

Hapich, H., 2019. Analiz prychyn hidrodynamichnoi avarii na hruntovykh hidrotekhnichnykh sporudakh kaskadu shtuchnykh vodoim [Analysis of the causes of hydrodynamic accident on the soil dams of the cascade of artificial reservoirs]. Bulletin of the National University of Water and Environmental Engineering. Vol. 1(85). 73-82. Retrieved from https://doi.org/10.31713/vt120198 (in Ukrainian).

Hogeboom, Rick J., Knook, Luuk, \& Hoekstra Arjen Y., 2018. The blue water footprint of the world's artificial reservoirs for hydroelectricity, irrigation, residential and industrial water supply, flood protection, fishing and recreation. Advances in Water Resources. 113. 285-294. Retrieved from https:// doi.org/10.1016/j.advwatres.2018.01.028

Khilchevskyi, V., Kurylo, S., Sherstyuk, N., \& Zabokrytska, M., 2019. The chemical composition of precipitation in Ukraine and its potential impact on 
the environment and water bodies. Journal of Geology, Geography and Geoecology. 28(1). 79-86. Retrieved from https://doi.org/10.15421/111909.

Khilchevskyi, V., Zabokrytska, M., \& Sherstyuk, N., 2018. Hydrography and hydrochemistry of the transboundary river Western Bug on the territory of Ukraine. Journal of Geology, Geography and Geoecology. 27(2). 232-243. Retrieved from https://doi.org/10.15421/111848.

Kulikova, D., Kovrov, O., Buchavy, Y., \& Fedotov, V., 2018. GIS-based Assessment of the Assimilative Capacity of Rivers in Dnipropetrovsk Region. Journal of Geology, Geography and Geoecology. 27(2). 274-285. Retrieved from https://doi. org/10.15421/111851.

Lapsenkov, V. S., 1983. Bez malyih rek net rek bolshih [Without small rivers there are no large rivers]. Rostov (in Russian).

Magilligan, F. J., Nislow, K. H., Kynard, B. E., \& Hackman, A. M., 2016 Immediate changes in stream channel geomorphology, aquatic habitat, and fish assemblages following dam removal in a small upland catchment Geomorphology. 252. 158-170. Retrieved from https://doi.org/10.1016/j.geomorph.2015.07.027.

Manyuk, V., 2017. Geological journeys of Valerian Domger to the basins of the rivers Omelnyk, Samotkan and Domotkan. Journal of Geology, Geography and Geoecology. 25(2). 89-98. Retrieved from https://doi.org/10.15421/111723.

Rebati, N., Bouchenafa, N., Oulbachir, K., \& Svideniuk, M., 2019. Remote sensing and ground based assessment of distribution of land cover parameters inthe catchment area of Wadi el K'sob M'sila (Algeria). Journal of Geology, Geography and
Geoecology. 27(3). 485-494. Retrieved from https://doi.org/10.15421/111872.

Reimers, N. F., 1990. Prirodopolzovanie: Slovar-spravochnik [Nature Management: Dictionary-Reference]. Moscow (in Russian).

Rudakov L., Hapich H., Orlinska O., Pikarenia D., Kovalenko V., Chushkina I., \& Zaporozhchenko V., 2020. Problems of technical exploitation and ecological safety of hydrotechnical facilities of irrigation systems. Journal of Geology, Geography and Geoecology, 29 (4), 776-788. Retrieved from https://doi.org/https://doi.org/10.15421/112070.

Shevchuk, S., Vyshnevskyi, V., Shevchenko, I., \& Kozytskyi, O, 2019. Doslidzhennia vodnykh obiektiv Ukrainy z vykorystanniam danykh dystantsiinoho zonduvannia [Research of water objects of Ukraine using the data of remote sensing of the earth]. Land Reclamation and Water Management. 2. 146-156 (in Ukrainian). Retrieved from https://doi.org/10.31073/mivg201902-198.

Vodnyi Kodeks Ukrainy. Postanova Verkhovnoi Rady №2 214/95-VR vid 06.06.95 [Water Code of Ukraine. Resolution of the Verkhovna Rada no. 214/95-VR from 06.06/95] (in Ukrainian).

Yatsyk, A. V., Byshovets, L. B., Bohatov, Ye. O. and ath., 1991. Mali richky Ukrainy: dovidnyk [Small rivers of Ukraine: directory]. Kiev: Urozhai (in Ukrainian).

Yu-jun, Yi, Zhou Yang, Song Jie, Zhang Shanghong, Cai Yanpeng, Yang Wei, \& Yang Zhifeng, 2019. The effects of cascade dam construction and operation on riparian vegetation. Advances in Water Resources. 131. Retrieved from https://doi. org/10.1016/j.advwatres.2018.09.015. 